\title{
Business clustering along the M1-N3-N1 corridor between Johannesburg and Pretoria, South Africa.
}

\author{
X Pillay ${ }^{1}$ and HS Geyer ${ }^{2}$
}

\begin{abstract}
${ }^{1}$ Statistics South Africa, Centre for Regional and Urban Innovation and Statistical
Exploration, Stellenbosch University, xavenp@statssa.gov.za

${ }^{2}$ Centre for Regional and Urban Innovation and Statistical Exploration, Department of

Geography and Environmental Studies, Stellenbosch University, *hssgeyer@sun.ac.za
\end{abstract}

\section{http://dx.doi.org/10.4314/sajg.v5i3.6}

\begin{abstract}
As a communication axis between Pretoria and Johannesburg the Old Pretoria Main Road always served as a linear force of attraction of urban development. This force was subsequently strengthened, first by the construction of the M1 and N1 motorways and later by the N3. Anecdotal evidence points to these sections of the motorways being one of the fastestgrowing urban corridors in South Africa. Using available aerial photography, together with the information from zoning and cadastral data, footprints of buildings within a 500 metre buffer from the centre line of the corridor were established. These footprints were used to identify 15 areas in which significant clusters of industry, commerce and services occur. A survey, combining different sources of information was subsequently conducted to distinguish between different groups of businesses along the corridor. Based on this information the types and rates of business clustering along these sections of the corridor from 2001 to 2012 were determined.
\end{abstract}

\section{Key Words}

Urban morphology; business clustering; corridor development; metropolitan development

\section{Introduction}

A vast array of businesses lines the sides of the N1, M1 and N3 highways between Pretoria and Johannesburg. It is apparent that specific locations along the highways tend to be preferred by different kinds of businesses. The lengths of these specific locations along the highways span 14 kilometres along the N1, 8 kilometres along the M1 and 10 kilometres along the N3. These sections of the highways, divided by the Buccleuch interchange, form part of two sections of the rapidly growing development corridor between the two core cities (Figure 1) and are gradually altering the morphology of the megalopolis. The motorways that formed these corridors are creating attractive spaces for the location of business, adding to the creation of business cumulative causation along the routes between the two core cities. In contrast, some of the former occupiers of the CBDs of the core cities have moved elsewhere 
due to a combination of factors - loss of clients, increasing cost-income differentials, lack of space in the cities, traffic congestion and risk of crime.

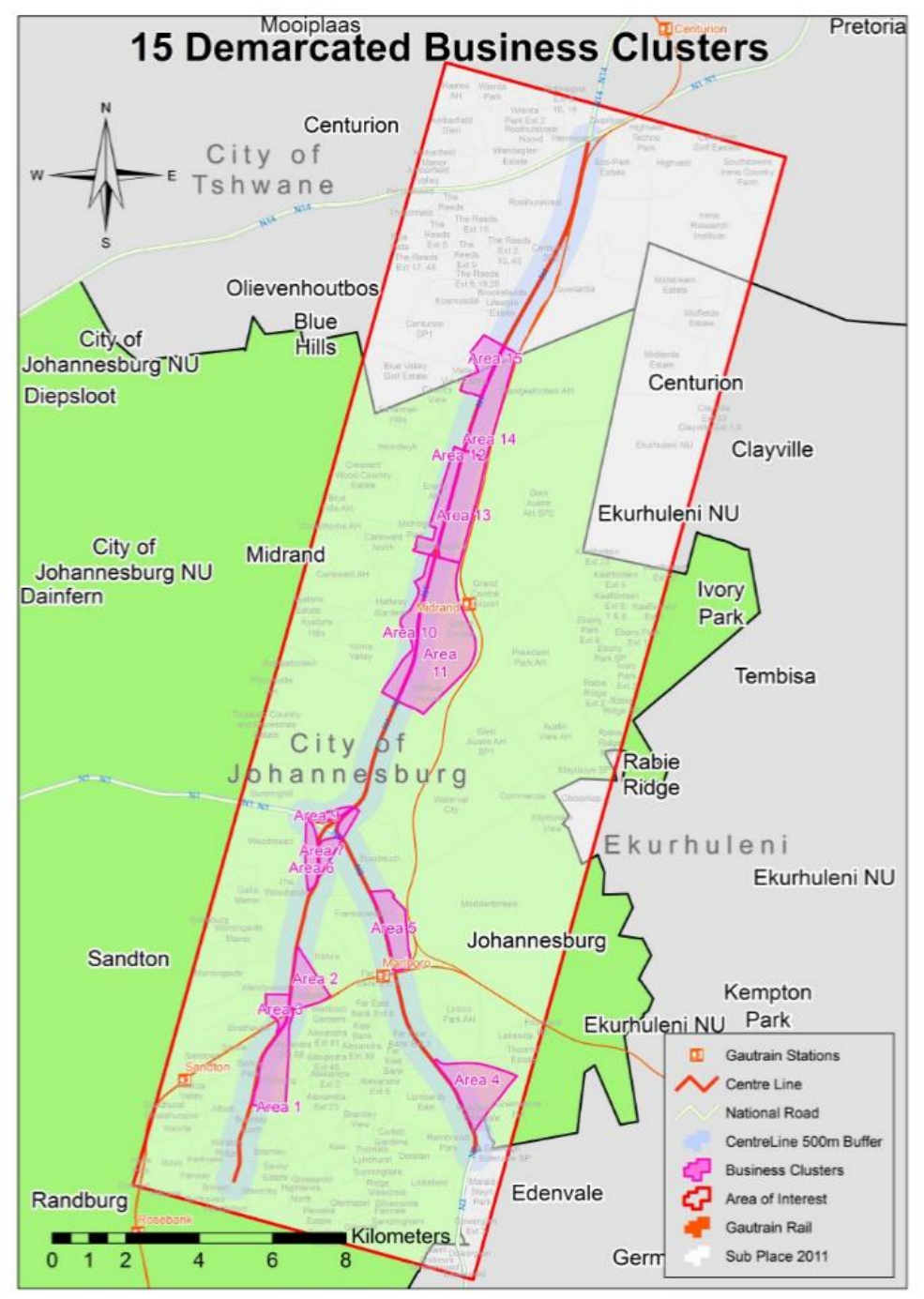

Figure 1 Locality plan showing the locations of study areas (business clusters) and buffer along the M1-N3-N1 corridor between Johannesburg and Pretoria

Well-established theoretical concepts underlie these processes. First, the combined effects of the abovementioned pull and push factors lead to urban development outcomes that resemble features of Burgess' and Hoyt's urban models (Pacione, 2009). Second, the central place theories of Christaller (1933) and Lösch (1940) have enhanced our understanding of the spatial organisation of the economy through the positioning of high order and low order goods and services in relation to market areas. These theories provide a good explanation of describing the hierarchical positioning of urban centres along the N1-M1-N3 corridors in an effort to minimise the friction of distance for the provision of goods and services to consumers (Rodrigue, 2014).

Hotelling's (1929, p.41) law stated that there is an "undue tendency for competitors to imitate each other in quality of goods, in location, and in other essential ways." The outcome of Hotelling's model entails firms strategically locating near each other in order to maximise 
their service areas (Henrickson, 2012). This spatial economic phenomenon may guide us in our understanding of why, based on the trade-off between cost savings related to energy, labour, land, external economies, and amenities on the one hand, and risk factors and access to markets on the other, firms tend to cluster in certain locations along the corridor. Similarly when looking at where the businesses tend to locate in this study area it could be argued that firms strategically chose to locate along the N1-M1-N3 to maximise their visibility and accessibility to more markets and in an effort to minimize risk factors and maximize profits.

Berry's (1967) classification of nodes, commercial ribbons and specialized areas gives us a greater understanding of the retail, office and warehousing patterns we see on the N1-M1-N3 today. The clustered, sometimes fragmented, rows of car dealerships, home fabrics and home furnishings and clothing districts in this paper's study areas can be linked to Berry's model. Guy (1998) and Borchert (1998) provide further analyses and explanations into the business configurations of Berry and enable us to better understand how these retail structures usually cluster together based on types of goods or services provided. Borchert (1998) provided insight into continuously changing demand and supply factors that lead to retail dynamism. The demand side focuses on the rapidly changing consumer preferences and shopping behaviour while the supply side entails the retail units' response to the changing economic conditions and increasing competition. It is these forces that have influenced retail business structures, an insight that is useful to this study and assists in the better understanding of why retail has developed in the areas along the N1-M1-N3 (Borchert, 1998). Guy (1998) on the other hand enhances our understanding of the retail configuration along the N1-M1-N3 by putting forward that retail areas in suburban areas "have grown through the conversions of residential and other property in order to serve neighbouring areas with convenience or occasionally comparison goods" (Guy, 1998)

Marshall (1920), Weber (1929), Hoover (1945), Isard (1956) and Parr (2002) all explained the role of scale, localisation and urbanisation economies as part of agglomeration economies. Together they determine the location of firms. Of these, localisation economies, according to Howitt (2004), Mayer (1996), McCann (2004) and Nafziger (2006), are the most important force. Agglomeration economies lead to larger, better endowed cities having a better chance of attracting more firms. Classical Weberian location theory states that profit seeking firms will be attracted to those locations where they will benefit from minimizing transport costs while Hoover explained thea locational pull of break-of-bulk sites in the location of businesses. Also locations where a number of firms are already in existence play a role in attracting businesses (Scott, 1982). The tendency of firms to cluster at particular locations (Das and Das, 2011) are explained by Porter's (1990) industrial cluster theory. All the locational factors referred to above could play a role in the clustering of firms at locations along the communication axis that connects the nodes along the corridors. In this sense the communication axis act as an elongated or 'axial' node (Geyer, 1988).

The push and pull factors resulting in the relocation of firms from inner city locations to outlying areas, as Scott (1982) explains, lie in the developments of truck transport and newly designed highways, the invention of horizontal plant layouts, cheap land in urban peripheral locations, the decentralization on the working population, proximity of some suburbs to 
airports and accessibility of the periphery to the residences of managers and staff. Recent trends have shown that peripheral locations are attractive to capital intensive firms (Scott, 1982).

Vast improvements in communication technology have led to many offices (Insurance; banking; finance; head offices and business services) and capital intensive firms moving away from the confinement of the city centre. In Gauteng, office developments are moving out of the city centres and are generally locating in higher-income and predominantly suburban areas such as Sandton. The reasons behind these locational decisions lie in the fact that these areas are characteristic of lower congestion, higher availability of amenities, greater ease of vehicle usage and the locations are in close proximity to middle and high income employees (Harrison et al., 2008). The movement of offices to these areas entails the servicing of a higher income local community in better surroundings.

The offices along the N1-M1-N3 also benefit from the exposure created from large numbers of commuters travelling by, giving these companies an added marketing advantage over competitors in more secluded places. Porter (1998) explains that clusters affect competition in three broad ways: firstly, they increase the productivity of companies based in that area; secondly, they drive the direction and pace of innovation, which underpins future productivity growth; and thirdly, this stimulates the formation of new businesses which expands and strengthens the cluster itself. The locational positioning also offers excellent infrastructural advantages to many of the local and multinational freight forwarding, warehousing and distribution companies along the routes - in essence increasing the efficiency of service to the clientele in their service areas. It was Oum and Park's (2004) research on distribution centres in Northeast Asian countries that revealed that multinational enterprises follow the following locational considerations: market size, transport accessibility, labour cost and availability and other input costs in the positioning of their firms (Hong, 2007).

A specific area of interest in this study is the clustering of high technology enterprises along the N1 corridor in Midrand. The formation of these clusters is driven by the grouping of command and control functions and training and service activities in specific areas. According to Rogerson (1998) the leading locational factors influencing the establishment of firms along this corridor are: centrality between Johannesburg and Pretoria; image; corporate visibility; and accessibility to the highway network.

In what he presents as "new economic geography" (NEG) Krugman (1991) regards economies of scale, labour, demand and transport cost under conditions of imperfect competition as important macro locational factors causing industrial cumulative causation i.e. continued concentration of industrial development in core regions at the expense of peripheries (Fujita \& Krugman, 2004). Following in the footsteps of Weber (1929), Hoover (1945), Greenhut (1956), Isard (1956) and many others on the impact of transport costs on the location and agglomeration of firms (see Smith 1970 and Geyer, 2007 for an overview), Krugman (1991) asserts that low transport costs are instrumental in centralising economic activities in space. On the other hand, centrifugal forces driven by high rents; aging and 
insufficient infrastructure; crime; and congestion are part of deglomeration forces pushing firms away from centralised locations (Richardson, 1973; 1980; Fujita \& Krugman, 2004). The resultant effect is economic space that tends to be strung out like strings of pearls - nodal and linear rather than geographically dispersed (Ottaviano \& Thisse, 2004). From this follows the argument that if businesses were to relocate within a metropolitan area chances are that they would either be located in or near existing nodes located somewhere along communication routes connecting them.

Rogerson (2010) refers to many studies that have shown the importance of agglomeration economics in the choice of location of firms and enterprises. Avandi (1997) argued that clusters offer crucial technological support systems in an information rich environment. This enables enterprises that are located within an agglomeration to benefit from technological externalities and collective technical support.

Research has shown how clustered low-order firms can take business away from nonclustered low order rivals and that clusters only arise at those locations that appear to be optimally positioned for low level and same level consumer purchases (Mulligan et al., 2012). Aside from low order clustering, Porter (1990), referenced in Engel and del-Palacio, (2009), made reference to clusters of innovation such as Silicon Valley, referring to them as frequently observed concentrations of interconnected organizations where proximity leads to shared advantages through the aggregation of expertise, intellectual property patents and specialized resources. In central place theory, retail trade and service activities often tend to cluster, forming central business centres at one geographic scale and lower order suburban shopping centres at another (Mulligan et al., 2012).

"Where firms cluster together, there are efficiency gains from outsourcing, labour pooling and knowledge spillovers" (Krugell and Rankin, 2012, p.299). Levy's (1993) World Bank study of the small medium and micro-enterprise (SMME) economy revealed that the most successful SMME manufacturing companies are generally run by educated and experienced entrepreneurs. This highlights Pred's (1967) empirical findings of the importance of the amount of information and the ability to correctly interpret that information when decisions regarding the locations relative to the types of enterprises are made. Porter (1998) mentions that the enduring competitive advantages in a global economy are often heavily local, arising from concentrations of highly specialized skills and knowledge institutions, rivals, related businesses, and sophisticated customers.

Aside from the above economic considerations in trying to understand the business clustering on the N1-M1-N3, Castell (1996) pointed to the importance of 'spatial economies of synergy.' Sharing space with a valuable partner in a particular network increases the possibility of adding value as a result of the innovation generated by this interaction. He sees metropolitan areas as likely breading grounds for such networks, acting as attractors of capital, talent or other valued factors (Blanco, 2014). Recently the US President Obama emphasised the importance of the clustering of enterprises, universities and financial institutions in creating environments for dynamic interaction (Lenchuk, E. B. \& Vlaskin, G.A., 2010) 
In light of the above mentioned theories and empirical research the evolution and composition of corridors is the next issue to be dealt with.

\section{The composition, functioning and classification of corridors}

The development corridor or axis concept has historically remained an important planning policy instrument at different levels of spatial aggregation in South Africa (South Africa, $1975 ; 1980 ; 1981 ; 1999 ; 2000 ; 2006 ; 2009 ; 2012$; CoCT, 2012). Brand et al. (2015) empirically demonstrated the relevancy of the concept within the context of the Gauteng megalopolis.

Although many different terms are found in planning, economic and geography literature describing the development corridor or axis concept, it can best be defined as a phenomenon that comes into being when economic interaction between two or more nodes - towns, cities or suburban centres - creates conducive conditions for further business development along the communication axis connecting the nodes (Geyer, 1988). Put another way, development corridors connect major nodes to create purposeful interaction that could result in highdensity development of both residential and commercial activities along the corridor (Donaldson, 2006). In the Draft National Development Plan of 1984 the South African government defined a development axis as a system of development centres situated on a communication axis near each other or as a linear manifestation of arteries emerging from the developing centres. The corridor forms a nodal line (Geyer, 1988). Socio-economic interaction along the communication axis turns it into a nodal line serving as a linear force of attraction and exerting a wider (regional) influence on its surrounding area (Gruber, 1980).

Geyer (1988) suggested that a development axis must have the following attributes to be regarded as a corridor: it must at least have a dominant development centre at either end of a communication axis linking the two; the development centres on the axis must be mutually dependant in order to support a relatively high volume of interaction along the axis between them; interaction on the axis must create potential for further development along the axis; and the axis must be physically and economically growing.

In the next section an analysis will be done of the changes that have occurred on a part of the main development corridor between Johannesburg and Pretoria. The focus is on the central part of the N1, N3 and M1 motorways

\section{The Analysis}

ESRI's ArcGIS 10.2 was used in all the spatial analyses. The study area, shown as the area of interest (AOI) in Figure 1 falls within the limits of what could be regarded as the fringes of the metropolitan areas of Johannesburg and Pretoria. The latest 2012 aerial photography obtained from the City of Johannesburg was used to determine a centre line following the N1-M1-N3. The spatial line was created following the heads up digitizing method of data capturing. A spatial proximity buffer of 500 metres was then created on either side of this centre line as an outer lateral limit of the corridor. For the purpose of analysis all the building 
footprints within this buffer were plotted. Apart from the locational selection processes, spatial joins were also carried out to update the attributes of the building footprints with the information from the zoning, cadastral and point layers. This gave the footprints more detailed information from which the analysis could be conducted. Next, 15 clusters of industry, commerce and services along the N1-M1-N3 were identified using the heads up digitizing method together with the 2012 imagery (see Figure 1). The demarcated areas incorporating the clusters served as study areas which enabled a detailed analysis of the areas along the routes. The analysis was then back-dated from 2012 to 2001, the earliest data set that was available for that decade.

The survey was conducted in phases. First, the Google Maps, Street View option was used to identify business types in the different study areas. This method proved to be generally useful in establishing point data but in cases where the tool was ineffective the survey was followed up by driving the different business areas to capturing outstanding businesses. Where it proved impossible to drive, businesses were captured on foot by means of a hand held GPS device. The GPS capture of areas proved very useful especially when compared to collected data from other data sources. It allowed judgement calls on which sources of data would prove more useful and which were inaccurate.

Table 1. Business clustering along the M1-N3-N1 corridor between Johannesburg and Pretoria, South Africa.

\begin{tabular}{|c|c|c|c|c|c|c|c|}
\hline $\begin{array}{l}\text { Clu } \\
\text { ster }\end{array}$ & $\begin{array}{c}\text { Count } \\
2001 \\
\text { Footprin } \\
\text { ts }\end{array}$ & $\begin{array}{c}\text { Count } \\
2012 \\
\text { Footprin } \\
\text { ts }\end{array}$ & $\begin{array}{l}\text { Total Area, } \\
2001\left(\mathrm{~m}^{2}\right)\end{array}$ & $\begin{array}{l}\text { Total Area, } \\
2012\left(\mathrm{~m}^{2}\right)\end{array}$ & $\begin{array}{l}\text { Business Cluster } \\
\text { Total Area }\left(\mathbf{m}^{2}\right)\end{array}$ & $\begin{array}{l}\text { Land used, } \\
2001(\%)\end{array}$ & $\begin{array}{l}\text { Land used, } \\
2012(\%)\end{array}$ \\
\hline 1 & 439 & 1173 & 468822 & 581187 & 1537682 & 30 & 38 \\
\hline 2 & 119 & 365 & 162711 & 193724 & 996267 & 16 & 19 \\
\hline 3 & 77 & 279 & 91478 & 126846 & 426796 & 21 & 30 \\
\hline 4 & 22 & 756 & 19646 & 581219 & 1952208 & 1 & 30 \\
\hline 5 & 154 & 778 & 198256 & 445239 & 1224842 & 16 & 36 \\
\hline 6 & 16 & 88 & 59005 & 130057 & 535797 & 11 & 24 \\
\hline 7 & & 3 & & 365 & 323666 & 0 & 0 \\
\hline 8 & & 5 & & 79 & 216778 & 0 & 0 \\
\hline 9 & & 27 & & 27840 & 223405 & 0 & 12 \\
\hline 10 & 124 & 556 & 100669 & 169004 & 1087096 & 9 & 16 \\
\hline 11 & 589 & 2612 & 665007 & 1005373 & 4790610 & 14 & 21 \\
\hline 12 & 35 & 291 & 70405 & 136765 & 958522 & 7 & 14 \\
\hline 13 & 338 & 966 & 376330 & 506962 & 1976893 & 19 & 26 \\
\hline 14 & 154 & 750 & 180952 & 354841 & 1637520 & 11 & 22 \\
\hline 15 & & 43 & & 114979 & 902596 & 0 & 13 \\
\hline
\end{tabular}

The point data (Figure 2) for 2001 and 2012 thus created were used in conjunction with the imagery for 2003 and 2012 to extract the building footprints for each year. This provided sets 
of layers for the buildings that existed in 2003 and 2012. The footprints of 2003 and 2012 made it possible to calculate the sums of the areas that were covered by development within each business cluster for the two years (Table 1). Inaccuracies with regards to the building foot prints were corrected for by comparing the datasets of COJ and GeoTerra Image by merging them and digitizing the 2012 building foot prints.

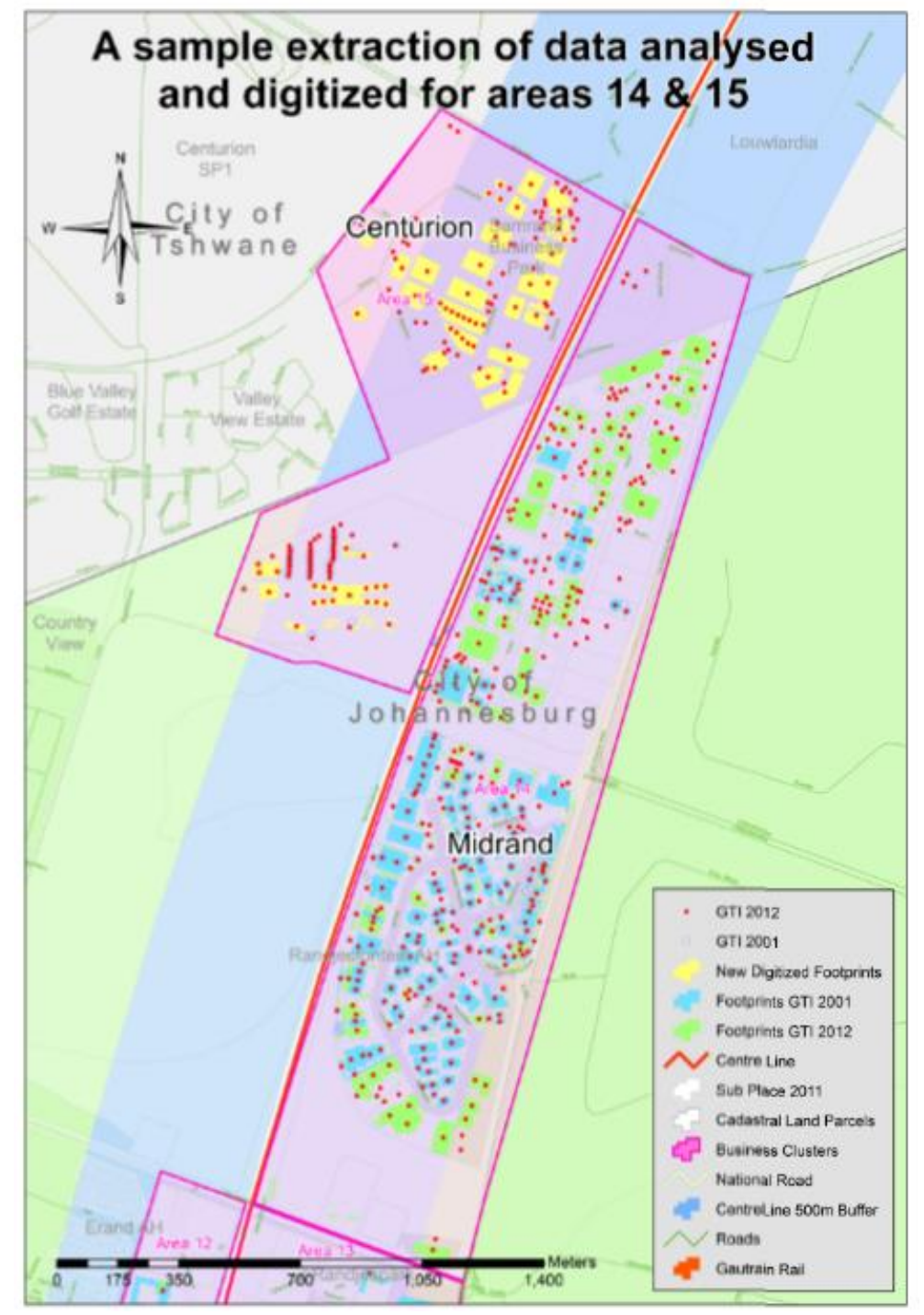

Figure 2 An example of point data and newly digitized footprints in a Study Area

The calculation of the differences in development per square metre clearly shows the degrees of spatial development that have occurred along the corridor between the years 2003 to 2012 . Aside from the footprint analysis, the aerial photography allowed an excellent visual interpretation of how the business areas have changed from 2003 - 2012 (see example of Area 4 in Figure 3). 

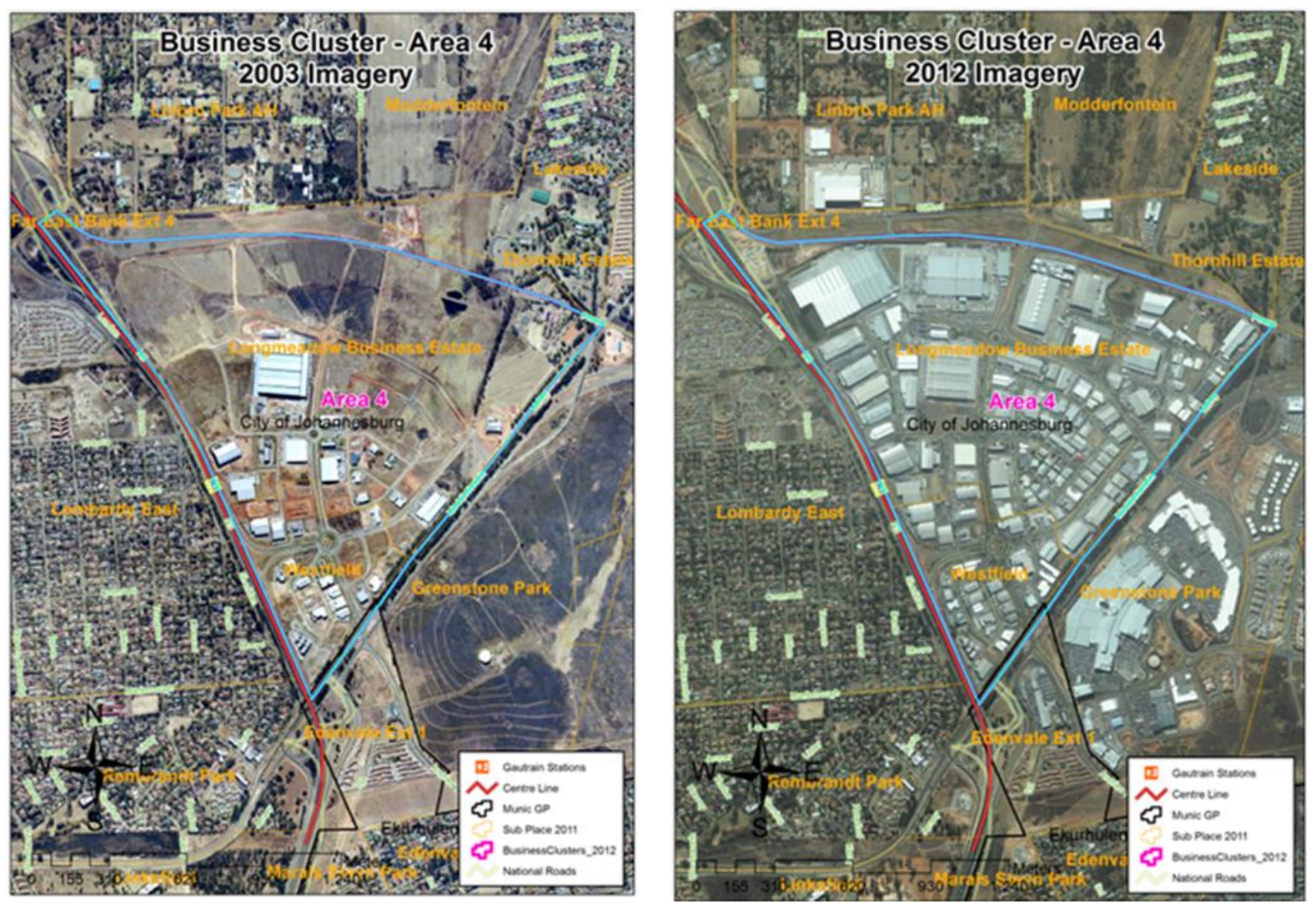

Figure 3 Changing land uses in study Area 4, 2003-2012

The results also show significant increases in development on the N1 and N3. Spatial Statistical Analysis was conducted using Geo Terra Image data for the years 2001 and 2012. A distributional directional analysis tool was used to measure the geographic distribution of the data. The tool also known as the standard deviational ellipse creates an ellipse around the distribution of the data. The results show how development according to the 2012 GTI nonresidential data has moved northwards on the N1 towards The City of Tshwane and eastward along the N3 compared to how the GTI data was distributed in 2001 (Figure 4). This reaffirms what was established in the aerial photography and the foot print development analysis - i.e. business development has intensified greatly on the N1 and N3 corridor. 


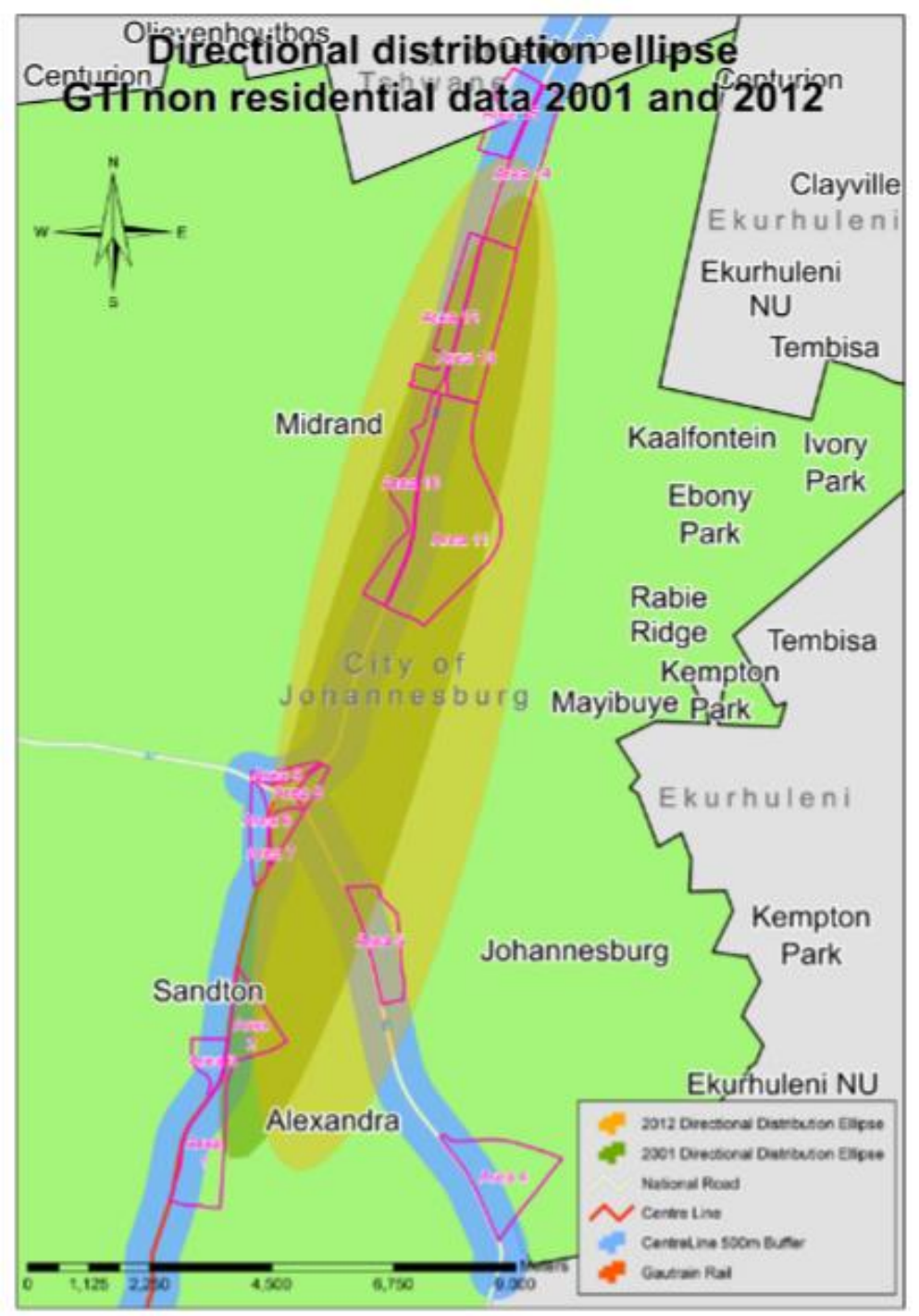

Figure 4 Standard deviational ellipse showing the trend in the distribution of new buildings along the corridor over the study period

\section{Survey of the number of businesses}

The survey of the Area 1 situated on the eastern side of the Grayston off-ramp revealed a cluster of home industry-related companies, motor vehicle, motor spare parts, and panel beating workshops. The area was also abundantly laden with furniture stores and factory shops selling business and home furniture. The survey also revealed a clustering of electrical and electricity related products and services. This provides a perfect example of how businesses agglomerate based on the principles of NEG. There were bigger warehouses located towards the northern end of the business cluster. These consist of company showrooms, manufacturing and administration all located on one business property.

On the eastern side opposite of Kramer Street in Area 2 are companies like Unitrans, Toyota, Lexus, adorning the sides of the highway. Large fashion and furniture retail outlets and head offices are also located in the area. The bigger companies like Cummins which manufacture diesel engines have their offices directly next to the manufacturing side of their business. 
This company which manufactures diesel engines is clustered with Toyota, Lexus. Also evident in the cluster is the Tripark business park which houses many media and film companies, similar to what has been witnessed diagonally across the highway in area 3 with the Sterkinekor and Primedia cluster.

The western side of the M1 in Area 3 is strewn with large businesses and warehouses located towards the Southern side of the cluster. There are many offices and business parks located in this area with companies requiring large space to conduct their business. There are clothing companies and medical supply companies that have their offices and manufacturing situated next to each other. The same can be said of the furniture holding company Ellerines which has made the area their head office. Security company ADT and media giant Sterkinekor and Primedia are also located in the area together with other related media firms of Primemedia.

Area 4 located near the Modderfontein off-ramp consists primarily of the Longmeadow Business Estate while the area on the western side opposite the business clusters is flanked by residential properties. The area is a bustling hub of huge warehouses, logistic companies, distribution depots, wholesalers, light manufacturers and service companies, most of which require spacious premises to carry out their business activities (Refer to Table 1). The central location of the business estate offers ease of access to Sandton, Midrand, OR Tambo Airport and the industrial basin on the East Rand along the highway routes. Evident from the results aside from the many clustered logistic companies are the close proximity and agglomeration of the food distribution warehouses belonging to Pick'n'Pay, Bidvest Foods and Nestlé. Although a detailed survey of individual businesses falls outside the scope of this study, there is scope for a follow-up study in which the focus could fall on strategic (agglomerationdriven) reasons why these companies strategically located in this fashion. An observation witnessed is the added proximity advantage that the wholesalers, manufacturing and production line companies have in situating so close to the numerous logistic companies. This most probably assists in their product distribution.

The business cluster demarcated as Area 5 is located along the eastern side of the N3 between the Marlboro off-ramp and Buccleuch interchange. Vacant land dominates the western side of the highway opposite the business cluster. Most of the businesses are located within the Linbro business park. The business park is home to a wide variety of corporate head offices, ICT companies, car dealerships and engineering solutions companies manufacturing motors, motor parts, specialist instrumentation or equipment. There are not as many large warehouses as are evident in Area 4. The analysis of the survey results provided the detail of the many ICT related companies as well as the many companies involved in the engineering of industrial motors, parts, equipment and instruments within the business park. A few car dealership head offices are also situated in the area.

High end designer studios featuring a multitude of home industry accessory companies from luxury designer furniture to designer kitchens and bathroom accessories are clustered in Area 6. The area along the highway tapers off into a mix of residential spaces with houses that have been converted into businesses together with large corporate offices of companies like 
SAGE making its way toward the Woodmead Retail Park complex and the Buccleuch interchange.

Areas 7, 8 and 9 situated at the Buccleuch off ramp have become thriving areas of development with industries giants such as Group 5, Oracle, Bytes Technology, Nashua, Cell $\mathrm{C}$, Vodacom and British Telecom establishing their business offices in the area. Some of the offices and warehousing of Waterfall City as well as shareholding and property developers Atterbury and Attacq - are located in Area 7 on the eastern side of the highway.

To the north along the $\mathrm{N} 1$ at the Buccleauh interchange there is a significant clustering of large IT companies - Oracle, Bytes, Altech, Nashua, etc., and medical firms: Bristoll Myers Squibb and Medtronic. Towards Allandale on the eastern side of the highway is Waterfall City. The mega Mall of Africa will also be built there. The area already holds the Waterfall hospital, some residential properties and offices. Also on the eastern side of the highway, overlooking the development on the western side, are more corporate offices of the property developers and Shareholdings Company Atterbury and Attacq.

In area 10 there is a complexity of office parks, corporate head offices and residential addresses situated along the western side of the N1. Waterfall Office Park, Siemens, Altech, Inveco, Varsity College, Riverview Park and Thornhill Park form some of the clusters of offices in the area. A number of educational facilities are also located close to each other: Varsity College, Unisa, Post Office learning institute, Netcare Training Academia and the Midrand Library. These institutions are situated within close proximity of each other as well as a few electronic companies - Scheider Electric, PFK Electronics and SVA Electronic.

Area 11 on the eastern side of the N1 contains a display of mostly light manufacturing, warehousing and head offices, the likes of BMW and Neotell. Large business parks such as Growth Point adorn the eastern side of the N1 opposite the Riverview and Thornhill office parks. The survey of areas located on the eastern side of the New Road off ramp reveals a high concentration of related medical company offices, medical laboratories, the cosmetic giant L'Oreal and pharmaceutical companies. The medical giant Johnson and Johnson have also located in business cluster Area 13 and their building is clearly visible from the highway. The area includes a mix of commercial and industrial business parks with huge warehousing displaying bays for receiving and dispatching. High technology companies have also agglomerated in the area with giants such as Pinnacle Africa, Mustek, MTN, Acer, HTC and TomTom all within a close proximity of each other.

Across Area 13, on the opposite side of the highway on the western side, immediately opposite Johnson and Johnson is the home of cellular giant Vodacom. The business cluster Area 12 has many related technology companies with dense clusters of offices and sectional title residential buildings. Vodaworld itself contains sections for business as well as retail shops that are related to their cellular service and bandwidth, extending to a wide variety of technology products including vehicle tracking devices. Located further to the north, towards the N14 on the eastern side of the N1 - flanking Midrand North and South Corporate Park 
and the N1 Business Park - is Area 14 (Figure 5) consisting of mixed commercial and industrial businesses and offices with mini units, warehousing and light manufacturing.

New developments are taking place in Area 15 (Figure 5) near the Samrand off ramp at Yen road. Up and coming ICT companies are settling in the area. Signposts of industrial and commercial stands up for sale are shown in the area. Names such as Esquire, Datacentrix and the Sizwe IT group have already settled in and between the developing construction sites. The area is also home to the N1 Industrial Park located towards the north of the current sprawling business cluster.
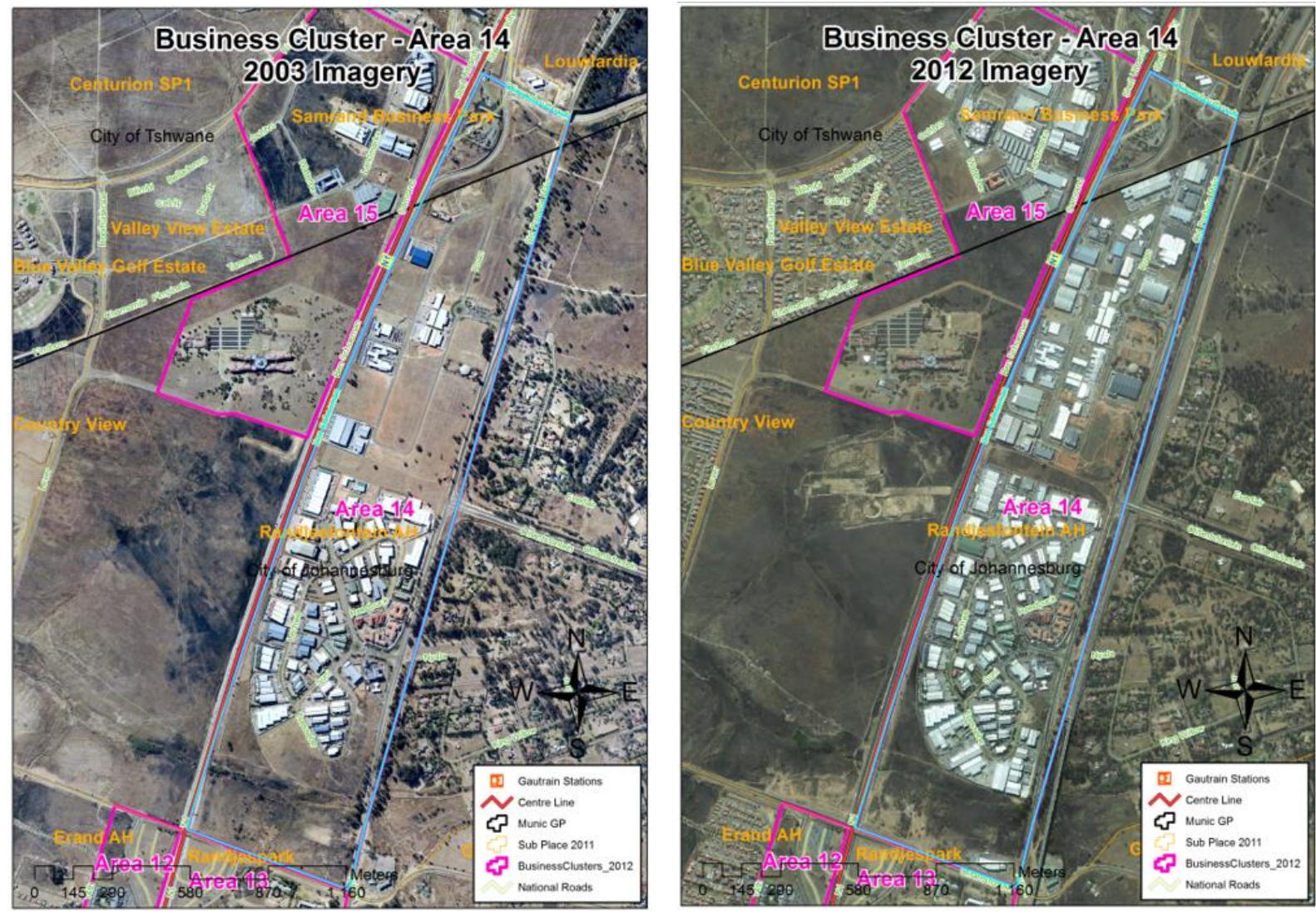

Figure 5 Changing land uses in study Areas 14 and 15, 2003-2012

\section{Conclusions}

In this paper an attempt has been made to determine the scale of development and to identify the kinds of businesses that have clustered in 15 areas along the N1-M1-N3 corridors between Pretoria and the Johannesburg-Germiston area between 2001 and 2012. The GIS analysis shows details of the new developments that have occurred in these areas. Existing and older business parks have been pushed to capacity resulting in new developments in all the areas investigated. The business clusters situated along the different sections of the highway represent a thriving development corridor with the highways serving as communication axes. These communication conduits not only increase accessibility but also improve visibility and brand exposure to firms located in the areas. 
The analysis has shown that the M1-N1 motorway has clearly been serving as an effective communication corridor along which corridor development have occurred over the study period. Johannesburg and Pretoria form the anchors on either end of the corridor while Sandton City, Midrand and Centurion serve as primary nodes along the corridor. Some parts of the available land along the corridor have evolved into prominent secondary clusters some fully developed, others filling fast. It is clear that the route from Grayston off-ramp on the M1 towards Samrand Avenue on the N1 could be regarded as a continuation of the same corridor. The N3, on the other hand, although growing fast, has not developed as much along the entire length of the corridor. This is evident in the large tracks of vacant land that still exist on either side of the highway. Together the N1, M1 and N3 could therefore be regarded as a forked corridor, fragmented by clusters of residential activity, commercial and industrial development, vacant land and mining activities.

Policy could have played an important role in the development of the corridor. Certain types of industries are being directed away from the inner city areas towards different areas along the highways and this has clearly benefitted the corridor. Not only does this promote movement away from the city centre, it also enables the multidirectional flow of traffic making better use of the highways. The establishment of the commercial and industrial business parks along the highways have bolstered attraction to the areas with business and corporate parks offering fully catered mini units and offices for small business, as well as light manufacturing and warehousing for distribution and logistics of bigger business enterprises. The business and corporate parks also offer substantial security access and control, an attribute that is welcomed by any sensible business owner.

The GIS analysis shows that Pretoria Main Road served as the initial corridor of development with many businesses locating along it. It also has many good examples of how business have established due to the principles of new economic geography. The development of the N1 has seen the movement of new business and business parks settling along the sides of the highways. Location, centrality and accessibility are great contributors to offices, light manufacturing, warehousing and distribution activities being located along these routes.

The N1-M1-N3 seems to be a maturing corridor fragmented by clusters of residential activity, commercial and industrial development, vacant land and mining activity. The three highways form a forked corridor of growing economic activity linking bustling nodes of development. The M1 from Grayston headed along Samrand on the N1 may be considered part of the same corridor.

The limitations to this study stem from the limited supply of datasets available on the businesses in Johannesburg. As mentioned earlier there were some inaccuracies with regards to the building foot prints, these however were corrected for by comparing the two datasets, merging them and digitizing new building foot prints. The time frame of this project did not allow for a detailed or holistic study of business clustering. A further corridor study at higher levels of spatial inclusion of Gauteng could also be used to link the phenomenon with network theory and provide greater insight into how the different nodes of economic activity 
function. This would definitely lead to better planning for infrastructure and economic development of different communities and economic hubs within the province.

\section{Bibliography}

Berry BJL, (1967). "Grouping and regionalization: An approach to the problem using multivariate analysis" in Garrison W.L. and D.F. Marble (eds.) Quantitative Geography. Part I: Economic and cultural topics. North Western University Studies in Geography, 13: 219-251

Blanco, H. (2014). Range of contemporary urban patterns and processes. Strungmann Forum Reports, 14.

Borchert, J. (1998). Spatial dynamics of spatial structure and the venerable retail heirarchy. GeoJournal, 45: 327-336.

Brand, A., Geyer H. S. and Geyer, H. S. Jr. (2015) Corridor development in Gauteng, South Africa. GeoJournal DOI 10.1007/s10708-015-9683-x

Castells, M. (1996), The rise of the network society, Oxford: Blackwell.

Christaller, W. (1933), Central places of Southern Germany, Baskin C.W. (trl) Englewood Cliffs, N.J.: Prentice-Hall.

CoCT (City of Cape Town). (2012). Cape Town spatial development framework. Western Cape Province, City Space, Planning Cape Town.

Das, R. and Das, A.K. (2011) Industrial Cluster: An Approach for Rural Development in North East India. International Journal of Trade. Economics and Finance, 2(2): 161-165

Donaldson, R. (2006). Mass rapid rail development in South Africa's metropolitan core: Towards a new urban form? Land Use Policy, 23: 344-352.

Engel, J.S. and del-Palacio, I. (2009). Global networks of clusters of innovation: Accelerating the innovation process. Business Horizons, 52(5): 493-503.

Fujita, M. and Krugman, P. (2004). The new economic geography: Past, present and the future. Regional Science, $83: 139-64$.

Geyer, H.S. (1988). The terminology, definition and classification of development axes. The South African Geographer, 16(1/2) :113-29.

Geyer, H.S. (2007). The evolving economic landscape: trends in the past and present, from local to global. In H. S. Geyer (ed.) International Handbook of Urban Policy: Contetious Global Issues, Vol 1. Edward Elgar: Cheltenham, UK. Pp. 38-58.

Greenhut, M.L. (1956), Plant location in theory and in practice, Chapel Hill: University of North Carolina Press. 
Gruber R. (1980) Vergleichende Analyse von Entwicklungsachsen als Elemente landesplanerischer Konzeptionen (im Rahmen punktaxialer Systeme). In Veröffentlichungen der Akademie für raumforschung und landesplanung: Kleinraumige Siedlungspsachen: Sur Anwendung linearere Siedlunsstrukturkonzepte, Rorschungs- und Sitzungsberichte, Band 133: 43-68 Hannover: Schroedel.

Guy, C. (1998). Classifications of retail stores and shopping centres: Some methodological issues. GeoJournal, 45 (4):255-264.

Harrison, P., Todes, A. and Watson, V. (2008). Transforming South Africa's cities: Prospects for the economic development of urban townships. Development Southern Africa, 14(1): 4360.

Henrickson, K.E. (2012). Spatial competition and strategic firm relocation. Economic Enquiry, 50(2): 364-379.

Hong, J. (2007). Location determinants and patterns of foreign logistics services in Shanghai, China. The Service Industries Journal, 27(4): 339-354.

Hoover, E.M. (1948). Location of economic activity, New York: McGraw-Hill.

Hotelling H. (1929). Stability in competition. Economic Journal, 39: 41-57.

Howitt, P., 2004. Endogenous Growth, Productivity and Economic Policy: A Progress Report. Rhode Island: Brown University.

Isard, W. (1956). Location and space-economy: a general theory relating to industrial location, market areas, land use, trade and urban structure, Cambridge, MA: MIT.

Krugell, W. and Rankin, N. (2012). Agglomeration and firm-level efficiency in South Africa. Urban Forum, 23: 299-318.

Krugman, P. (1991). Increasing returns and economic geography. Journal of Political Economy, 99: 483-499.

Levy, B. (1993). Obstacles to developing indigenous small and medium enterprises: An empirical assessment, World Bank Economic Review, 7(1): 65-83

Lenchuk, E. B. and Vlaskin, G. A. (2010). The cluster approach in the innovation development strategy of foreign countries. Studies on Russian Economic Development, 21(5): 484-492.

Lösch, A. (1954). The economics of location, New Haven: Yale University Press.

Marshall, A. [1890] (1920). Principles of economics, London: Macmillan.

Mayer, J., 1996. Implications of new trade and endogenous growth theories for diversification policies of commodity-dependent countries. UNCTAD/OSG/DP/122.

McCann, P., 2004. Urban and Regional Economics. Oxford: Oxford University Press. 
Mulligan, G.F., Partridge, M.D. \& Carruthers, J.I. (2012). Central place theory and its reemergence in regional science. Annual Regional Science, 48: 405-431.

Nafziger, E.W., 2006. Economic Development, 4th Edition. Cambridge New York: Cambridge University Press.

Ottaviano, G. and J.-F. Thisse (2004). New Economic Geography: what about the N?, CORE Discussion Paper No. 2004/65, Leuven: Catholic University of Leuven.

Oum T.H. and Park, J. H. (2004) 'Multinational firms,' location preference for regional distribution centres: focus on the Northeast Asian region. Transportation Research E: Logistics and Transportation Review, 40: 101-121.

Pacione, M. (2009). Urban Geography, A Global Perspective. London: Routledge.

Parr, J.B., (2002). Agglomeration economies: ambiguities and confusions. Environment and Planning A, 34: 717-731.

Porter, M.E. (1990). The competitive advantage of nations. New York: The Free Press.

Porter, M.E. (1998). Clusters and the New Economics of Competition. Boston, Massachusetts: Harvard Business School.

Pred, A. (1967) Behavior and location: Foundations for a geographic and dynamic location theory. Part I, The Royal University of Lund, Department of Geography Studies in Geography Series B (Human Geography) Nos. 27 \& 28 / Lund: C.W.K. Gleerup.

Richardson, H. W. (1980). Polarization reversal in Developing Countries, Papers of the Regional Science Association, 45: 67-85.

Richardson, H. W. (1973). Economic growth theory. London: MacMillan.

Rodrigue, J.-P., (2014). Transport and spatial organisation. [Online] Dept. of Global Studies \& Geography, Hofstra University, New York, USA Available at: https://people.hofstra.edu/geotrans/eng/ch2en/conc2en/ch2c3en.html [Accessed 14 July 2014].

Rogerson, C.M. (1998). High Technology clusters and infrastructure development: international and South African experiences. Development of Southern Africa, 15(5), pp.875905.

Rogerson, C.M. (2010). Growing the SMME manufacturing economy of South Africa: Evidence from Gauteng Province. Journal of Contemporary African Studies, 19(2): 267-291.

Scott, A.J. (1982). Locational patterns and dynamics of industrial activity in the modern metropolis. Urban Studies, 19: 111-142.

Smith, D.M. (1970), Industrial location: an economic geographical analysis, New York: John Wiley and Sons. 
South Africa (1975). National physical development plan. Office of the Prime Minister. Government Printer. Pretoria.

South Africa (1980). A spatial development strategy for the PWV-complex. Office of the Prime Minister. Government Printer. Pretoria.

South Africa (1981). Good hope plan of South Africa. Department of Foreign Affairs and Information. Government Printer. Pretoria.

South Africa (1999). National Department of Transport: Moving South Africa: The action agenda. Pretoria.

South Africa (2000). Department of Transport: National Land Transport Transition Act, 2000 (Act No. 22 of 2000).

South Africa (2006). National spatial development perspective: The Presidency. Pretoria.

South Africa (2009). National urban development framework: Harnessing a common vision for growth and development of South Africa's towns, cities and city-regions. Pretoria: Department of Cooperative Governance and Traditional Affairs and The Presidency and in partnership with the South African Cities Network.

South Africa (2011). The Gauteng spatial development framework. Gauteng ProvinceEconomic Development RSA.

South Africa (2012). National development plan 2030. Sherino: Printers Boksburg.

Weber, A. (1929). Theory of the location of industries, Friedrich, C. J. (trl.) Chicago: University of Chicago Press. 